\title{
Doing gender well: Women's perceptions on gender equality and career progression in the South African security industry
}

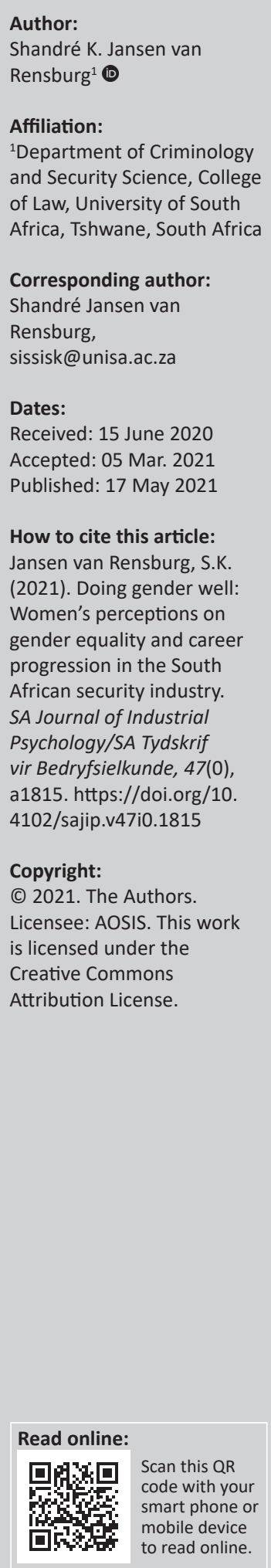

Author:

Rensburg ${ }^{1}$

\section{Affiliation:}

and Security Science, Colleg of Law, University of South Africa, Tshwane, South Afric

Corresponding author:

Rensburg

sissisk@unisa.ac.za

Accepted: 05 Mar. 2021

How to cite this article: Jansen van Rensburg, S.K. (2021). Doing gender well: progression in the South African security industry. vir Bedryfsielkunde, 47(0), a1815. https://doi.org/10

Copyright: Licensee: AOSIS. This work is licensed under the Creative Commons Attribution License.

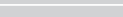

\begin{abstract}
Orientation: Although significant progress has been made globally in gender equality, women still occupy less political influence, fewer leadership positions and yield less control over their careers than most men. Gender inequality is evident in male-dominated work environments such as the security industry.
\end{abstract}

Research purpose: This study reflects on women's perceptions on gender equality and career progression in the South African security industry.

Motivation for the study: In post-democracy South Africa, women are categorised as previously disadvantaged, therefore a priority group in terms of advancement. However, it is still unclear, from the narratives of the women themselves, how their career progression is encumbered in the milieu of the security industry.

Research approach/design and method: Through qualitative one-on-one semi-structured interviews, 15 women, working in the security industry, shared their experiences concerning gender equality and career progression. Data were analysed thematically, guided by the context of the gendered security profession.

Main findings: The findings reveal that women experience slower career progression than men in terms of rejection and work allocation. Moreover, negative perceptions of female leadership among colleagues was a factor hindering career progression.

Practical/managerial implications: This study argues by doing gender well, equality in the security workplace can be obtained. Furthermore, the study encourages South African security managers to recognise how aspects such as rejection, work allocation and a negative perception of female leadership may encumber the career progression of female security professionals.

Contribution/value-add: The study contributes to scientific knowledge and discourse regarding women's perceptions on gender equality and career progression.

Keywords: gender; gender equality; career progression; security industry; rejection; work allocation; female leadership.

\section{Introduction}

Women empowerment is integral for sustaining economies and ultimately improving the quality of life for men and women, their families, communities and society at large (Ackermann \& Velelo, 2013; UN Women, 2017). As is evident in South African statistics, women are increasingly entering the workplace, constituting $43.8 \%$ of the labour force (Statistics South Africa, 2018), and are, thus, contributing significantly towards the economy. This incline is attributed to a variety of reasons. Barker (2007) suggested the primary reasons to be the declining birth rate, the decrease of women being dependent on employed men (for reasons such as death of partners, unemployment of men, divorce or single parenthood), as well as an increasing number of formally educated women. In addition, the increase in remuneration and access to jobs, because of the decrease in gender discrimination, are contributing factors to the proliferation of women in the labour force. As gender is viewed in a binary way, the female is treated as 'other' and not as equal (Acker, 1990). In South Africa, statistics substantiate this by revealing that the workforce is benign to men, and that men are more likely to be in paid employment when compared with women. As explained by the expanded definition of unemployment, females account for $7.5 \%$ points higher than males (Statistics South Africa, 2018). In 2019, the rates of unemployment were estimated to be $31.3 \%$ and $27.2 \%$ amongst women and men, respectively (Statistics South Africa, 2019). Furthermore, the data reveal that gender equality is still below the halfway mark for 
women occupying the influential positions. Moreover, only $32 \%$ of women occupy a managerial position in South Africa. Men monopolise every occupation, including the security industry, besides domestic work or clerical occupations (Statistics South Africa, 2018).

In post-democracy South Africa, women are regarded as a previously marginalised group and have been placed as a priority on the government's mandate (Ackermann \& Velelo, 2013). This mandate was substantiated through the Employment Equity Act, No. 55 of 1998, which advocates against discrimination and promotes equality (Republic of South Africa). Ideally, men and women should be equal contributors to the labour force, especially in positions of influence and power. Gender inequality in the workplace is an incessant topic under investigation (Ainsworth, 2019; Billing \& Alvesson, 2000; Booysen \& Nkomo, 2020; Head, 2018; Mcdonald, 2013; Memon \& Jena, 2017; Nentwich \& Kelan, 2014; Phipps, 2002; Wilén \& Heinecken, 2018). Nevertheless, gender inequality continues to prevail particularly in the security industry of South Africa. Moreover, the female narrative on gender equality and career progression needs to be explored as a contribution to bridging this gap.

Industries specialised in security services tend to be largely male dominated. This trend is substantiated by local (Govender, 2012; Kole, 2015; Louw-Vaudran, 2015) and international (Eichler, 2013; Goldfine, 2014; Hinton \& Friedman, 2016) research findings. This male-dominated work environment has implications on the career advancement of the women working there. In current news, issues of gender, particularly in favour of women, have been pushed to the forefront (Corcuera, 2017; Frye, 2018). However, this study argues for gender equality in the workplace as opposed to female superiority. The study contends that there is space in the security industry for both men and women if the gendering of professions is recognised and performed well. Gender differences should be recognised and celebrated. The contextual background sets the tone for the premise of the gendered discourse within the South African security industry.

\section{Literature review Contextual background}

Although strides have been made globally in the gender equality movement, women still have less political influence, maintain fewer leadership positions and yield less control over their own future careers when compared with most men (Roseberry \& Roos, 2014). These variables are rooted in remuneration inequality. In 2016, data obtained from a census revealed that women earned 80.5 cents for every $\$ 1$ earned by men. These figures remained unchanged in 2017 (Institute for Women's Policy Research, 2018; Picchi, 2018). Consequently, women are losing more than \$10 000 annually because of the pay gap, contributing to increased levels of poverty and decreased retirement security (Picchi, 2018). In
South Africa, women earn 28\% less than their male counterpart. Furthermore, South African part-time female employees (as compared with men) are ranked the second worst of countries surveyed for wage inequality (Head, 2018). The South African gender pay gap reveals that men earn up to $17 \%$ more than women. Subsequently, a woman would need to work two additional months in a year to earn a man's equivalent annual salary (Bosch, 2015).

The question arises: why does this remuneration gap exist? Because of gender stereotypes, boys and girls are encouraged to pursue different occupations. Men and women possess inherent neurobiological and genetic differences. These differences are further reinforced by socialisation in that most women are nurturing and empathetic, while men are aggressive and competitive. Consequently, men are socialised to outperform women in the workplace (Butler, 2014; Picchi, 2018; Roseberry \& Roos, 2014). Thus, many women are less likely to aspire for higher paying positions, resulting in lower earnings across their lifespan. A research study indicates that women are paid less than men as soon as they enter the workforce (Picchi, 2018). In this way, women are trapped into earning less over time, as remuneration is often negotiated based on previous earnings. Moreover, women lag behind men concerning remuneration and career progression because of child-bearing and child-rearing responsibilities (Walsh, 2012). Organisations seem to prefer employees who sustain interminable careers (Roseberry \& Roos, 2014). Accordingly, women's earnings decrease for each child they have, while conversely, men's earnings are increased when they have children (Picchi, 2018).

Considering the above, why are issues surrounding gender equality not persistently and strategically advocated for. In recent media coverage, especially on social media, gender inequality has been catalysed to the forefront on an international level through movements, such as '\#MeToo' and '\#femaleisthefuture'. The former movement seeks to expose sexual abuse and harassment among women, regardless of when it was committed (Frye, 2018). The latter encourages women empowerment and the expansion of female influence (Corcuera, 2017). As commendable as these movements are, this study contends that they may promote female dominance, and thus, create a reverse model of gender imbalance. The \#femaleisthefuture movement endorses the demise of men, and encourages female rule and reign over men. In this way, men are alienated and, in turn, young men can be socialised into believing that they are less than and inadequate. Moreover, this movement elucidates a bleak and hopeless future for the male child (Bian, Leslie, \& Cimpian, 2017). Subsequently, campaigning that women are better than men may be regarded as an overly regressive approach to gender equality. This regressive approach fuels the notion that neither men nor women have a real choice in gender equality. Equal opportunity only becomes effective when everyone (regardless of gender) is equally encouraged to seize those opportunities (Sandberg, 2013). 


\section{The gendering of the security profession}

'Doing gender' is a term extensively used when theorising gender in organisational studies. By 'doing gender', gender can now be perceived as a social practice - something that is said and performed (Acker, 1990; Britton, 2000; Davies, 1996; Kelan, 2008; McDonald, 2013; Nentwich \& Kelan, 2014; Phipps, 2002). West and Zimmerman (1987) put forth in their seminal body of work that gender is created in structures and does not merely exist in a vacuum. Furthermore, they maintain that gender is pertinent in every social situation. Nentwich and Kelan (2014) developed a topology to analyse 'doing gender' in empirical studies. The following themes emerged from their findings.

\section{Structures}

Gendered structures are rooted in jobs where gender identity is created and maintained. Often, the gender of the job influences the way people do their jobs. Moreover, the requirement of the gendered job is to perform duties that are stereotypical of a certain gender. The security industry is still gendered as a masculine profession (Erickson, Albanese, Drakulic, 2000, Govender, 2012; Kole, 2015) and it continues to be reinforced by traditional aspects of masculine security (Chisholm, 2017). Furthermore, there is a persistent underlying belief system that safety, security and protection is a 'man's job'.

\section{Hierarchies}

Hierarchies in terms of 'doing gender' can lead to inequality in the workplace as masculine qualities are valued and praised, while feminine qualities are perceived as inferior and unprofessional. Particularly in a male-dominated environment, femininity is at risk of being disregarded and undervalued. Within the international milieu, the most powerful organisational positions are occupied by men, as the top of the hierarchy (Acker, 1990). Out of 195 independent countries in the world, only 17 are governed by women, as they hold less than $30 \%$ of seats in parliament globally (Sandberg, 2013). This picture is not much different within the security industry. Although cybersecurity is fastdeveloping as society is dependent on technology as a security mechanism, female professionals in the field make up less than $15 \%$. It was found that even though women held higher qualifications, they still earned less than men and often experience discrimination in their workplaces (Gregory \& Wyatt-Swanson, 2018).

\section{Identity}

Individuals tend to find a deep sense of their identity in their gender. Thus, they carry out their occupations within these gendered norms. Moreover, their identities are constructed through emphasising or deemphasising specific facets of the job. As the security industry is male gendered, men are free to act out their masculine identities, while women work hard to minimise their feminine aspects and embrace any masculine traits they may possess.

\section{Flexibility and context specificity}

Despite the above-mentioned themes, gender is still recognised in terms of flexibility and context. Individuals perform gender differently across time and environment. Thus, when exploring gendered professions, aspects such as specific profession, context and environment, need to be reviewed in its fluidity. The study contextualises gender in the South African security context as a male-dominated industry, thus having implications on the women who work in it.

\section{Relevant and subverted gender}

Research on gender should explore gender when it is made relevant and explore situations where gender is undermined. Hence, gender should be explored when it is done and undone. Gender is both done and undone in the security industry, however by recognising these subverted themes, gender can be done well.

Key definitions pertinent to understanding shared meaning are outlined below.

\section{An overview of concepts relevant to the gendering of professions}

1. Gender: The differences between men and women are based on physical, social and cultural attributes (LloydJones, Bass, \& Jean-Marie, 2014). It indicates two or more subdivisions, which are distinct from each other, such as masculine or feminine (Oakley, 2016). Gender is a central way of determining power in relationships (Acker, 1990).

2. Gender discrimination: The unfair treatment or creation of an intimidating environment in the workplace stems from gender-based belief systems (Lloyd-Jones et al., 2014). This leads to unequal conduct towards men and women, which involves deficiency of a fair return for effort made (Cotter, 2017).

3. Gender equality: It is a social structure, in which women and men will share equal opportunities and challenges regarding their role in the economic and domestic milieu (Lloyd-Jones et al., 2014).

4. Gender gap: This means differences produced in the outcomes that men and women attain in the workplace. These differences constitute the following: the ratio of men and women in the workplace, the occupations they choose and their remuneration packages (Goldin, 2019).

5. Security industry: The term 'security' denotes the notion of being free from harm, risk and danger. This definition is further extended, in that it entails the measures taken to guard against any form of espionage, sabotage, crime, attacks or escape (Byres \& Cusimano, 2010). For the purpose of this study, the security industry is referred to as any working environment where the primary function is to promote and offer safety and security services.

\section{Goal of the study}

This study sought to explore and describe women's perceptions on gender equality and career progression in the South African security industry. It endeavoured to answer 
TABLE 1: Demographic profile of participants.

\begin{tabular}{|c|c|c|c|c|c|c|}
\hline Pseudonym & Population group & Age (years) & Marital status & Dependents & Occupation & Occupational rank \\
\hline Ashley & White population & 32 & Married & 2 & Academic & Entry level \\
\hline Bahira & Indian population & 31 & Not married & 0 & Academic & Entry level \\
\hline Chipo & Black population & 45 & Not married & 3 & Security officer & Entry level \\
\hline Didi & Black population & 44 & Divorced & 2 & Manager & Junior level \\
\hline Eleanor & Coloured population & 32 & Married & 0 & $\begin{array}{l}\text { Information and Communications } \\
\text { Technology security official }\end{array}$ & Senior level \\
\hline Fran & White population & 42 & Divorced & 2 & $\begin{array}{l}\text { Chief explosive trace detection } \\
\text { practitioner }\end{array}$ & Senior level \\
\hline Gonste & Black population & 43 & Divorced & 2 & Security officer & Entry level \\
\hline Hiya & Indian population & 24 & Not married & 0 & Project manager & Junior level \\
\hline Ingrid & White population & 79 & Widow & 2 & Admin administrator & Junior level \\
\hline Janet & Black population & 27 & Married & 3 & Technical administrator & Junior level \\
\hline Khadeeja & Indian population & 29 & Not married & 0 & Admin manager & Senior level \\
\hline Lynn & White population & 63 & Married & 1 & Admin assistant & Junior level \\
\hline Margaret & White population & 57 & Married & 1 & Senior manager & Senior level \\
\hline Olwethu & Black population & 41 & Married & 1 & Deputy director & Executive level \\
\hline
\end{tabular}

the following research question: what are the perceptions of women concerning gender equality and career progression within the security industry?

\section{Methodological framework Research paradigm}

A paradigm is the way in which an individual perceives the world. It is described as a model sustained by continuous assumptions used for collecting and interpreting information (De Vos \& Strydom, 2011). This study is routed in objectivism. Objectivity seeks to understand social situations as they really are. Although this paradigm is often used in quantitative studies, qualitative researchers acknowledge that the reality of participants can be revealed objectively (Fouché \& Schurink, 2011).

\section{Research approach}

This study adopted a qualitative methodology when exploring women's perceptions on advancing in the security industry. Glaser and Strauss (2017) ascertained that the qualitative process encourages the research participants to share the meaning and understanding they have attributed to their personal experiences. Reality is perceived and experienced in its complex, multifaceted, subjective and ever-changing nature (Creswell, 2007). Thus, the way each participant experiences their context is unique.

\section{Research strategy}

A phenomenological methodology was used in this study. Phenomenology is invested in the meanings of the lived experiences as perceived by the research participants. It is dependent on the research participants because it unpacks the phenomenon as perceived through their experiences. Subsequently, the findings are interconnected to the current research (Delport, Fouché, \& Schurink, 2011).

\section{Research procedure}

A non-probability and purposive sampling method was used to select participants to take part in the research study. The participants were purposively targeted based on their experiences as women working in the security industry. Creswell (ed. 2009) substantiated that small samples are useful when exploring lived experiences.

The sample consisted of 15 female participants, with ages ranging from 24 years to 79 years (see Table 1). The interviews were recorded, with the consent of the participants, and transcribed by the author. Within the South African context, it is important to document race, as it has historical and cultural implications for the individual. ${ }^{1}$ The sample varied with regard to race, marital status and dependents. Just over half of the participants (six) stated that they were married, while five identified themselves as not married. Three participants reported that they were divorced, and one is a widow. Most of the participants (11) revealed that they have children, while only four listed that they have no dependents. Moreover, their occupations varied within the security industry. For the purposes of this study, it is important to note participants' level of seniority within their work environment, ranging from the entry to executive level.

\section{Data collection}

The study used in-depth interviews to collect data. This entails the execution of rigorous and intensive interviews with a small number of participants in order to extract their experiences and perceptions on the topic at hand (Boyce \& Neale, 2006). Furthermore, a semi-structured one-on-one interview schedule was used in order to guide the interview process (Greeff, 2011). One-on-one interviews with 15 participants were set up based on their willingness and availability to take part in the study. The interviews were conducted in English and took 20-90 min to complete. The study is limited by its small sample size; however, qualitative research emphasises quality over quantity.

1.Racial categories are still significant in South Africa because of the apartheid classification system. 'White' refers to people with pale skin and European decent. 'Coloured' is not a derogatory term but rather a race group categrised by people 'Coloured' is not a derogatory term but rather a race group categorised by people with a mixed heritage (black and white). 'Black' refers to people with an African descent and who have darker skin, while 'Indians' are Asian people whose ancestry lineage can be traced back to India (Seekings, 2008, p. 3). 


\section{Data analysis}

The raw data were analysed by thematic analysis delineated by Braun and Clarke (2006). Data were familiarised by reading and re-reading the transcriptions of the interviews. Preliminary codes were identified and documented. Themes and sub-themes within the data were extracted, and then these themes and sub-themes were refined into categories. Thereafter, the themes were given clear labels and definitions, and the final report was prepared in the form of a research article.

\section{Ethical considerations}

The study received ethical approval from the College of Law Research Ethics Review Committee, University of South Africa (UNISA), reference number: P2/2017. This approval covered aspects such as informed consent, voluntary participation, avoidance of harm and confidentiality (Davies \& Francis, 2011; Ruane, 2016). The participants consented to their involvement in the study and were assured of data confidentiality using pseudonyms. In order to endorse the validity and reliability of the data, no incentives were provided for participation in the study. Credibility and authenticity were enhanced by describing and identifying the participants' lived experiences accurately. Dependability was fostered by documenting the research in a rational, peer-reviewed manner. Moreover, conformability and transferability were fostered by engaging in a rigorous process of literature review to contextualise the raw data (Schurink, Fouché, \& De Vos, 2011).

\section{Findings and discussion}

The following themes are derived from the empirical data: rejection, work allocation and the negative perception of female leadership.

\section{Rejection}

The research study suggests that rejection is one of the most harmful stressors in modern life. Rejection is a social threat that may undermine an individual's social worth, esteem and status (Ronen \& Baldwin, 2010). Men are inherently more accustomed to rejection than women are, resulting in greater resilience against it. This is pertinent to both social and professional environments (Devillard, Hunt, \& Yee, 2018). Furthermore, Devillard et al. (2018) maintained that men are often assessed on their potential, while women are evaluated based on their accomplishments. Women receive less praise for their successes, when compared with men, and more reproach for failure. Rejection sensitivity refers to the belief system adopted by people from stigmatised backgrounds, specifically women, who perceive rejection as probable and costly. As a result, they prioritise guarding themselves against possible rejection (London, Downey, Romero-Canyas, Rattan, \& Tyson, 2012). Rejection in the work environment is manifested in many ways. The following are some of the verbatim responses concerning rejection experienced by the participants of this study:

'I look at my male counterparts and they often exaggerate. They [men] will boast about things and I think to myself, "Is that really a big deal?" This is how they [men] are climbing the ladder. They [men] shout the little things which I think are part of my job. I see it in interviews as well. I look back on the men we hired a few years ago. The ones who were modest and quiet are my top achievers today. The ones with the big mouths ... [sighs] those are the little nuances that make us [women] different to men. We [women] tend to downplay our achievements while they [men] take a trumpet and tell it to the world. This makes them [men] appear to be better than women, which is not always the case. Men are naturals at selling themselves. It doesn't even take them a lot of effort to do so. Most men don't struggle with rejection. You reject me - no problem, I will go next door. That is why we [women] are not climbing the ladder fast enough because when I am being shot down, it's personal, even when it wasn't meant to be personal, whereas with a man, its water off a duck's back. So, you didn't like me, so what, I'm going to pitch this to someone who is going to like me. Whereas as with women, when we pitch something and get shot down, we become more wary and will not easily go and pitch it to the next person'. (Nandi, 50-year-old woman, senior-level employee)

Nandi highlights that in her work environment, women underplay their achievements, while men magnify their achievements. Budworth and Mann (2010), Butler (2014) and Devillard et al. (2018) supported this sentiment, as the research study suggests that women tend to be less assertive in the workplace and understate their value and contributions. Subverted gender roles are adopted as the female gender is undermined (Nentwich \& Kelan, 2014). Moreover, men do not take rejection personally and will easily look for recognition and acceptance somewhere else, whereas women harp on these negative experiences:

‘My supervisor asked me why I have never applied for a senior post. I answered him honestly to say, "I don't think you will give me a post." When advertisements are made, names are already heard about who will get that specific post'. (Chipo, 45-year-old woman, entry-level employee)

'Men have always been taken seriously in the boardroom and anywhere else. For example, a woman may have a solution on how to deal with a certain challenge; however, it will not be listened to. Later, a man who suggests the same solution to this challenge is then praised and given a pat on the back'. (Didi, 44-year-old woman, senior-level employee)

'Currently, there are more women with diplomas than there are males, but they don't get higher positions. The work environment doesn't allow us [women] to question such things. Now, when there is a position, we [women] don't even apply because we know they [management] have already earmarked a specific person for the position. They will even let the person they want for the position, know that it is theirs. They will phone the person and say, "apply, don't worry about the interview questions, I will give it to you." These things make you know where you stand. It doesn't matter how hard you work. It's a boys' club. They even drink and socialise together. When men graduate with their diplomas, they don't wait long until they get promoted, even though we have very intelligent women. An interview is made up of different 
panelists. Once the interviews are over, information leaks. You will find that your answers will be mocked among colleagues. It is very demotivating ... if you think about these things for too long, it will make that you won't even want to get out of bed in the morning. It's hard to challenge the system because you are just a drop in the ocean'. (Gonste, 43-year-old woman, entry-level employee)

The above verbatim experience illustrates how rejection or perceived rejection can be dangerously demotivating to the career progression of women working in the security industry.

Statistically, women make up more than $40 \%$ of the worldwide workforce, of which only $24 \%$ occupy senior positions (Catalyst, 2018). Within the work setting, the research study indicates that women are not as determined as men to pursue leadership roles, promotion, job transfers or high-profile assignments (Brands \& Fernandez-Mateo, 2017). In a study conducted on 10000 senior executives in the United Kingdom, the findings revealed that women, when compared with men, were significantly less likely to apply for a job if they have been previously rejected for a similar position. Moreover, the findings argue that this difference is noteworthy because rejection is a common practice in the workplace. Thus, this difference can have negative consequences for women, subsequently contributing to the gender gap. Additionally, the study found that women placed a significant value on the fairness of the recruitment and selection process, as they linked this to their own sense of recognition and belonging (Brands \& Fernandez-Mateo, 2017).

\section{Work allocation}

Societal values emphasise the importance of promotions in the workplace (De Pater, Van Vianen, \& Bechtoldt, 2010). However, the incongruity between men and women becomes evident, in that women tend to experience a slower career progression than men do (De Pater et al., 2010). Notably, many variables influence an individual's career success; yet, the literature proposes that work allocation is a significant factor contributing to career progression (De Pater et al., 2010). Women are often discriminated against men in safety and security environments; however, discrimination is particularly emphasised in combat and active roles. Resistance stems from perceptions that women cannot keep up with the physical requirements, women are more peaceful than men, and thus, are not suited for military and/or the presence of women affects the solidity of troops (Wilén \& Heinecken, 2018). Through these inherent structures, the perception that men are the only gender deemed fit to provide safety and security is maintained (Nentwich \& Kelan, 2014). The following experience of Eleanor echoes the current literature concerning women and the military:

'Although gender equality is actively discussed and implemented in this area, many women are mostly employed as support personnel and not in the battle arena. There are visibly fewer women than men in combat roles. Women are also excluded from unique and highly scarce roles. Restrictions are set on women based on what they [management] think women can handle'. (Eleanor, 32-year-old woman, senior-level employee)

Historically, women were discriminated against men both lawfully and socially. In ancient times, women were defined as 'mutilated males'. Furthermore, men were seen as being psychologically and biologically superior to women (Roseberry \& Roos, 2014). Although no longer legalised or socially acceptable, women are often still perceived as the 'weaker' sex in industries specialising in safety and security. Society portrays men as protectors for vulnerable people, such as women and children. Thus, it may be difficult to instil the same trust in women who seek to occupy a similar role. Subsequently, women working in safety and security industries are given administrative, menial and organisational tasks despite their qualifications or position. This affects their opportunities for advancement, promotion and overall job satisfaction. Ashley and Bahira share a common sentiment practised in the security industry. Despite relevant qualifications or a clear job description, women are delegated to menial and administrative tasks (Michelman, 2017):

'On my level, men expect women to do the admin type of work. I've noticed if minutes need to be taken, a woman needs to take it. If procurement jobs need to be done - it's a woman. They [men] will put you in a position where you [women] do admin jobs rather than leading a project. They [men] still have that mentality that women are not equal to men. There are more men than women on the same level, but the women are always given admin work, whereas males are capable of doing it but are not given the jobs. This has happened to me personally in terms of taking minutes, doing all the administration and the organisation of a project. I think they [men] think that women organise better, so all the little jobs go to women - arranging catering and getting venues are women-tasked jobs. The problem is, if you get stuck with tasks such as organising conferences and administrative work, it takes a lot of time out of your schedule. It doesn't allow you to focus as much on the tasks you need to do to improve yourself and advance in your career. You would get rewarded more for doing tasks that grow your career as compared to administrative tasks'. (Ashley, 32-year-old woman, entry-level employee)

'The challenge is that the men in our [security] industry view us [women] as being subordinates ... because of that, every menial task is dished out to us [women]. Men don't have that challenge. The way tasks are delegated in staff meetings is ridiculous. Our line manager is a male, and he assigns tasks in a biased way. He tends to give the administrative tasks to women. Even though it affects me a lot, I think nothing will be done about it, so it's just a big waste of time and energy'. (Bahira, 31-year-old woman, entry-level employee)

Ingrid and Hiya shed light on how there is a limited scope for women to progress in the security industry. Ingrid highlights that in her company, no training is provided for women, whereas Hiya notes that no technical training is given to women:

'I don't really think women can progress to top management. There are not a lot of people who can come in and replace them so that they [women] can move up. Management doesn't seem to see much scope for women. There's no training for women. You 
come in, you do your job and that's it'. (Ingrid, 79-year-old woman, junior-level employee)

'We [women] are given opportunities, but it isn't seen as important to give women technical training. In that way, we [women] could have a holistic view of how the company runs'. (Hiya, 24-year-old woman, junior-level employee)

This study argues that the less scope women are given concerning responsibility and training, the more difficult it would be for them to advance in their careers.

\section{Negative perception of female leadership}

Leadership denotes the influential abilities of an individual to stimulate and empower others to contribute towards the efficiency and success of an organisation (Van Emmerik, Wendt, \& Euwema, 2010). Leadership is often associated with masculine qualities, such as assertiveness, emotional detachment, superiority, task-centeredness, autonomy and independence (Billing \& Alvesson, 2000). As individuals carry out their roles within their gendered norms, feminine traits are minimised and undervalued (Nentwich \& Kelan, 2014). Subsequently, as detailed below, qualities that do not fit in this mould can be undermined, especially when not presented in a masculine structure:

'Initially, it was difficult for my male colleagues. What does a woman know about crime? Most of the criminals are males so what does a woman know about the way a man thinks? I needed to prove that I knew what I was doing. When a man says something, it is easily accepted because they have the knowledge and expertise'. (Margaret, 57-year-old woman, senior-level employee)

'My institution still has a lot of men who are very protective of their territories. It is what it is. When you look at the executive team - I can only think of one woman. It is still very much maledominated. What helps the number is that most managers are women, but when you look at the top, it is mostly males. Sometimes you will see a woman excelling and climbing the corporate ladder. You will expect her to get a promotion, but then suddenly a male is appointed. We [women] don't do golf, so clearly we don't have conversations in the right places. Men tend to question you more as a woman. This happens in the security industry a lot because it is male-dominated. When I took over my current role, the man who had it previously, still works with us. Our work is intertwined. We work well together. In some meetings, if I say something, the staff will look to him to rubber stamp it. Initially, I used to be offended. Then I thought it actually has nothing to do with me. I can't change their perception of me. Hopefully, if he keeps on rubberstamping me long enough, they will believe me. Look at these boys' clubs. We [women] don't have girls' clubs. I will use the example of golf. I don't play golf maybe that's why I am not climbing the ladder fast enough. The number of deals that are happening on the golf course ... I am old school which is worse. I don't even drink alcohol. If I go to a function, I get bored very quickly because there are only so many cokes I drink before I leave. Whereas the men will go and sit at a bar until 2 in the morning and of course there is no child waiting for them. They function in environments where it's easy for them to share, give each other tips and help each other out. Those are the things we [women] need'. (Nandi, 50-year-old woman, seniorlevel employee)
The research study suggests that women face more barriers in attaining leadership positions when compared with men (Van Emmerik et al., 2010). Women may need to prove themselves in their working environments, thus creating an added pressure. Feminine leadership does not fit into the perception of what a leader should be, according to the hierarchies the workplace subscribes to (Nentwich \& Kelan, 2014). Nandi points out that women make up most of the low- and middlemanagement roles, thus appearing to meet equity quota. However, men still occupy top-level management structures. Furthermore, Nandi alludes to the conducive work environment men have created for themselves. An ethos of exclusion is sustained through the absence of female voices and the presence of male patterns of networking (Toni \& Moodly, 2019). Men make it easy for men to succeed in terms of mutual encouragement, operational guidance and practical assistance. In her working environment, Nandi mentions the absence of such conductivity for women. Counterproductively, the research study indicates that once women achieve success, they notice gender discrimination less, particularly in genderbias work environments (Vinnicomber, Doldor, Sealy, Pryce, \& Turner, 2015).

Additionally, women are perceived as caring and nurturing; consequently, carrying the biggest load when it comes to caregiving within the family. Caregiving is often extended beyond children, and can include parents and frail family members (Lloyd-Jones et al., 2014). This is true within the African principle spirit of Ubuntu [kindness and assistance to others], whereby women extend themselves to nurture and care for those close to them. Acker (1990) ascertained that in a gendered industry, the ideal worker has minimal to no caregiving responsibilities as a spouse or another caregiver takes care of these responsibilities. This traditional belief system is encumbrance to women's career trajectories in male-dominated work environments. This is evident in the way Nandi perceives women's roles in an African context. Furthermore, Olwethu raises the challenges in managing men, as women in leadership positions are viewed as inferior and likened to their own interpersonal relationships:

'I had encounters where male subordinates would not take instructions as required due to my gender. I manage and monitor security companies, which are male-dominated. There was no cooperation due to my gender. I will receive statements such as "I won't listen to a woman"; or "A woman can't tell me what to do"; or "I have left my wife at home, so no woman can tell me what to do"'. (Olwethu, 41-year-old woman, executive-level employee)

The above extract highlights the innate patriarchal belief systems often found in the African culture (Jaga, Arabandi, Bagraim, \& Mdlongwa, 2017). The research study reveals that women may feel obliged to adopt an androgynous professional style to appease male management and both male and female subordinates (Herbst, 2020). The lines between work and personal life seem to be blurred as Olwethu's subordinates struggle to submit to her leadership. This is common in the South African context as the workplace promotes black female excellence, and therefore, sidelines 
black men (Booysen \& Nkomo, 2010: Bosch, De Bruin, Kgaladi, \& De Bruin, 2012). Naturally, this can cause cataclysm in gender relationships.

\section{Conclusion}

Women empowerment is vital for fuelling economies and improving the quality of life. Although issues surrounding women empowerment should be continuously advocated for, caution should be exercised to avoid creating a reverse model of gender imbalance by striving for women to be in a superior position. Women working in the security industry encounter more challenges in their career advancement compared with men. These challenges should be recognised and strategically dealt with. This study has found that challenges, such as rejection, work allocation and the negative perception of female leadership, remain prevalent in the South African security industry. South African security professionals occupying influential positions should acknowledge the negative consequences of these findings on gender equality and career progression for female employees, and should work towards overcoming them. This can be performed through awareness campaigns amongst both genders strategically targeting these challenges.

\section{Acknowledgements}

The author would like to thank those who participated in the study.

\section{Competing interests}

The author declares that they have no financial or personal relationships that may have inappropriately influenced them in writing this article.

\section{Author's contributions}

S.K.J.v.R. is the sole author of this research article.

\section{Funding information}

The research work was funded by the College of Law (UNISA) by providing the author time to conduct this research study during her research and development leave.

\section{Data availability}

Raw data are stored electronically on a password-protected laptop.

\section{Disclaimer}

The views and opinions expressed in this article are those of the author and do not necessarily reflect the official policy or position of any affiliated agency of the author.

\section{References}

Acker, J. (1990). Hierarchies, jobs, bodies: A theory of gendered organizations. Gender and Society, 4(2), 139-158. https://doi.org/10.1177/089124390004002002
Ackermann, L., \& Velelo, N. (2013). The position of women in the South African labour force: An overview. Botswana Journal of African Studies, 27(1), 153-168.

Ainsworth, E. (2019). Exploring women's perceptions of gender equality employee engagement programmes in the South African corporate environment. Unpublished MA dissertation. Johannesburg: University of Johannesburg.

Barker, F. (2007). The South African labour market: Theory and practice. Pretoria: Van Schaik.

Bian, L., Leslie, S., \& Cimpian, A. (2017). Gender stereotypes about intellectual ability emerge early and influence children's interests. Science, 355(6323), 389-391. https://doi.org/10.1126/science.aah6524

Billing, Y.D., \& Alvesson, M. (2000). Questioning the notion of feminine leadership: A critical perspective on gender labelling on leadership. Gender, Work and Organization, 7(3), 144-157. https://doi.org/10.1111/1468-0432.00103

Booysen, L.A., \& Nkomo, S.M. (2010). Gender role stereotypes and requisite management characteristics: The case of South Africa. Gender in Management:
An International Journal, $25(4), \quad 285-300$.
https://doi.org/10.1108/ An International

Bosch, A. (2015). Women are still paid less than men in South African companies Retrieved from https://theconversation.com/women-are-still-paid-less-thanmen-in-south-african-companies-45782

Bosch, A., De Bruin, G.P., Kgaladi, B., \& De Bruin, K. (2012). Life role salience among black African dual-career couples in the South African context. International Journal of Human Resource Management, 23(14), 2835-2853. https://doi.org/10. 1080/09585192.2012.671506

Boyce, C., \& Neale, P. (2006). Conducting in-depth interviews: A guide for designing and conducting in-depth interviews for evaluation. Retrieved from http://www2. pathfinder.org/site/DocServer/m e tool series indepth interviews. pdf?doc $I D=6301$

Brands, R., \& Fernandez-Mateo, I. (2017). Women are less likely to apply for executive roles if they've been rejected before. Retrieved from https://hbr.org/2017/02/ women-are-less-likely-to-apply-for-executive-roles-if-theyve-been-rejectedbefore

Braun, V., \& Clarke, V. (2006). Using thematic analysis in psychology. Qualitative Research in Psychology, 3(2), 77-101. https://doi.org/10.1191/1478088706 qp063oa

Britton, D.M. (2000). The epistemology of the gendered organization. Gender and Society, 14(3), 418-434. https://doi.org/10.1177/089124300014003004

Budworth, M., \& Mann, S.L. (2010). Becoming a leader: The challenge of modesty for women. Journal of Management Development, 29(2), 177-186. https://doi org/10.1108/02621711011019314.

Butler, R. (2014). Motivation in educational contexts: Does gender matter? In L.S Liben \& R.S. Bigler (Eds.), The role of gender in educational contexts and outcomes (pp. 1-41). London: Elsevier.

Byres, E., \& Cusimano, J. (2010). Safety and security: Two sides of the same coin Retrieved from http://www.controlglobal.com/articles/2010/safetysecurity1004/

Catalyst. (2018). Quick take: Women in the workforce - Global. Retrieved from https:// www.catalyst.org/research/women-in-the-workforce-global/\#footnote4 xmh4ddp

Chisholm, A. (2017). Clients, contractors, and the everyday masculinities in global private security. Critical Military Studies, 3(2), 120-141. https://doi.org/10.1080/ 23337486.2016.1273297

Corcuera, U. (2017). Feminism does not mean that the future is female. Clark Chronicle. Retrieved from https://clarkchronicle.com/opinion/2017/10/13/ feminism-does-not-mean-that-the-future-is-female/

Cotter, A.M. (2017). Gender injustice: An international comparative analysis of equality in employment. London: Taylor \& Francis.

Creswell, J.W. (2007). Qualitative inquiry and research design: Choosing among five approaches. Thousand Oaks, CA: Sage.

Creswell, J.W. (Ed.). (2009). Research design: Qualitative, quantitative, and mixed methods approaches (3rd edn.). Los Angeles, CA: Sage.

Davies, C. (1996). The sociology of professions and the profession of gender. Sociology, 30(4), 661-678. https://doi.org/10.1177/0038038596030004003

Davies, P., \& Francis, P. (2011). Preparing criminological research. In P. Davies, P. Francis, \& V. Jupp (Eds.), 2011. Doing criminological research (2nd edn.). London: Sage.

Delport, C.S.L., Fouché, C.B., \& Schurink, W. (2011). Theory and literature in qualitative research. In A.S. De Vos, H. Strydom, C.B. Fouché, \& C.S.L. Delport (Eds.) Research at grass roots: For the social sciences and human service profession (4th edn., pp. 297-306). Pretoria: Van Schaik.

De Pater, I.E., Van Vianen, A.E.M., \& and Bechtoldt, M.N. (2010). Gender differences in job challenge: A matter of task allocation. Gender, Work and Organization, 17(4), 433-453. https://10.1111/j.1468-0432.2009.00477.x

Devillard, S., Hunt, V., \& Yee, L. (2018). Still looking for room at the top: Ten years of research on women in the workplace. McKinsey Quarterly. Retrieved from https://www.mckinsey.com/featured-insights/gender-equality/still-looking-forroom-at-the-top-ten-years-of-research-on-women-in-the-workplace

De Vos, A.S., \& Strydom, H. (2011). Scientific theory and professional research. In A.S. De Vos, H. Strydom, C.B. Fouché, \& C.S.L. Delport (Eds.), Research at grass roots: For the social sciences and human service professions (4th edn., pp. 28-44). Pretoria: Van Schaik.

Eichler, M. (2013). Gender and the privatization of security: Neoliberal transformation of the militarized gender order. Critical Studies on Security, 1(3), 311-325. https:// doi.org/10.1080/21624887.2013.848107 
Erickson, B.H., Albanese, P., \& Drakulic, S. (2000). Gender on a jagged edge: The security industry, its clients and the reproduction and revision of gender. Work security industry, its clients and the reproduction and revision of gender. Work
and Occupations, 27(3), 294-318. https://doi.org/10.1177/0730888400 027003003

Fouché, C.B., \& Schurink, W. (2011). Qualitative research designs. In A.S. De Vos, H. Strydom, C.B. Fouché, \& C.S.L. Delport (Eds.), Research at grass roots: For the social sciences and human service professions (4th edn., pp. 307-327). Pretoria: Van Schaik.

Frye, J. (2018). From politics to policy: Turning the corner on sexual harassment. Centre for American Progress. Retrieved from https://www.americanprogress. org/issues/women/news/2018/01/31/445669/politics-policy-turning-cornersexual-harassment/

Glaser, B.G., \& Strauss, A.L. (2017). The discovery of grounded theory: Strategies for qualitative research. New York, NY: Routledge.

Goldfine, S. (2014). Where security pros stand? Retrieved from http://www. securitysales.com/images/pdf/SSI_2014_Security_Industry_Demographic Census.pdf

Goldin, C. (2019). Gender gap. The Library of Economics and Liberty. Retrieved from https://www.econlib.org/library/Enc/GenderGap.html

Govender, D. (2012). Management of security information in the security industry. Unpublished PhD thesis. Pretoria: University of South Africa.

Greeff, M. (2011). Information collection: Interviewing. In A.S. De Vos, H. Strydom, C.B. Fouché, \& C.S.L. Delport (Eds.), Research at grass roots: For the social sciences and human service professions (4th edn., pp. 341-374). Pretoria: Van Schaik.

Gregory, D., \& Wyatt-Swanson, R. (2018). The changing role of women in the security industry. Retrieved from https://www.securityindustry.org/2018/10/12/thechanging-role-of-women-in-the-security-industry/

Head, T. (2018). Gender pay gap: Four charts that show a shocking gulf between SA men and women. Retrieved from https://www.thesouthafrican.com/gender-paygap-south-africa-charts/

Herbst, H.H. (2020). Gender differences in self-perception accuracy: The confidence gap and women leaders' underrepresentation in academia. SA Journal of Industrial Psychology, 46(0), 1-8. https://doi.org/10.4102/sajip.v46i0.1704

Hinton, T., \& Friedman, K. (2016). Women in security: Changing the narrative Retrieved from http://www.ifpo.org/news/women-security-changing-narrative/

Institute for Women's Policy research. (2018). Pay equity and discrimination. Retrieved from https://iwpr.org/issue/employment-education-economic-change/payequity-discrimination/

Jaga, A., Arabandi, B., Bagraim, J., \& Mdlongwa, S. (2017). Doing the 'gender dance': Black women professionals negotiating gender, race, work and family in postapartheid South Africa. Community, Work \& Family, 21(4), 429-444. https://doi.or $\mathrm{g} / 10.1080 / 13668803.2017 .1311840$

Kelan, E.K. (2008). Emotions in a rational profession: The gendering of skills in ICT work. Gender and Society, 15(1), 49-70. https://doi.org/10.1111/j.14680432.2007.00355.x

Kole, O.J. (2015). Partnership policing between the South African Police Service and the private security industry in reducing crime in South Africa. Unpublished PhD thesis. Pretoria: University of South Africa.

Lloyd-Jones, B., Bass, L., \& Jean-Marie, G. (2014). Gender and diversity in the workforce. In M.Y. Byrd \& C.L. Scott (Eds.), Diversity in the workforce: Current issues and emerging trends (pp. 77-103). New York, NY: Routledge.

London, B., Downey, G., Romero-Canyas, R., Rattan, A., \& Tyson, D. (2012). Genderbased rejection sensitivity and academic self-silencing in women. Journal of Personality and Social Psychology, 102(5), 961-979. https://doi.org/10.1037/ a0026615

Louw-Vaudran, L. (2015). African women are increasingly part of the military and police, but these remain strongly male-dominated institutions. Retrieved from https://www.issafrica.org/iss-today/women-in-africas-top-brass-its-not-justabout-the-numbers

Mcdonald, J. (2013). Conforming to and resisting dominant gender norms: How male and female nursing students do and undo gender. Gender, Work and Organization, and female nursing students do and undo gender. Gender, Work and
20(5), 561-579. https://doi.org/10.1111/j.1468-0432.2012.00604.x
Memon, N.Z., \& Jena, L.K. (2017). Gender inequality, job satisfaction and job motivation: Evidence from Indian female employees. Management and Labour Studies, 42(3), 253-274. https://doi.org/10.1177/0258042X17718742

Michelman, B. (2017). Managing and escaping stereotypes and obstacles. In S.J. Davies (Ed.), Women in the security profession: A practical guide for career development (pp. 5-10). New York, NY: Elsevier.

Nentwich, J.C., \& Kelan, E.K. (2014). Towards a topology of 'doing gender': An analysis of empirical research and its challenges. Gender, Work and Organization, 21(2), 121-134. https://doi.org/10.1111/gwao.12025

Oakley, A. (2016). Sex, gender and society. London: Taylor \& Francis.

Phipps, A. (2002). Engineering women: The 'gendering' of professional identities. International Journal of Engineering Education, 18(4), 409-414. https://doi org/10.1111/j.1468-0432.2012.00589.x

Picchi, A. (2018). Four ways women earn less than men. Retrieved from https://www. cbsnews.com/news/4-ways-women-earn-less-than-men/

Republic of South Africa. Employment Equity Act, No 55 of 1998. Published in the Government Gazette (19370). Cape Town: Government Printer.

Ronen, S., \& Baldwin, M.W. (2010). Hypersensitivity to social rejection and perceived stress as mediators between attachment anxiety and future burnout: A prospective analysis. Applied Psychology: An International Review, 59(3), 380-403. https://doi.org/10.1111/j.1464-0597.2009.00404.x

Roseberry, L., \& Roos, J. (2014). Bridging the gender gap: Seven principles for achieving gender balance. Oxford: Oxford University Press.

Ruane, J.M. (2016). Introducing social research methods: Essentials for getting the edge. West Sussex: Wiley-Blackwell.

Sandberg, S. (2013). Lean in: Women, work and the will to lead. London: Random House.

Schurink, W. Fouché, C.B \& De Vos, A.S (2011). Qualitative data analysis and interpretation. In A.S. De Vos, H. Strydom, C.B. Fouché, \& C.S.L. Delport (Eds.), Research at grass roots: For the social sciences and human service professions (4th edn.). Pretoria: Van Schaik.

Seekings, J. (2008). The continuing salience of race: Discrimination and diversity in South Africa. Journal of Contemporary African Studies, 26, 1-25. https://doi. org/10.1080/02589000701782612

Statistics South Africa. (2018). Quarterly Labour Force Survey. Retrieved from http:// www.statssa.gov.za/publications/P0211/P02112ndQuarter2018.pdf

Statistics South Africa. (2019). Quarterly Labour Force Survey. Retrieved from https:// www.statssa.gov.za/publications/P0211/P02114thQuarter2019.pdf

Toni, N.M., \& Moodly, A.L. (2019). Do institutional cultures serve as impediments for women's advancement towards leadership in South African higher education? South African Journal of Higher Education, 33(3), 176-191. https://doi. org/10.20853/33-3-3137

UN Women. (2017). Women's empowerment principles. Retrieved from http://www. unwomen.org/en/partnerships/businesses-and-foundations/womensempowerment-principles

Van Emmerik, H., Wendt, H., \& Euwema, M.C. (2010). Gender ratio, societal culture, and male and female leadership. Journal of Occupational and Organizationa Psychology, 83, 895-914. https://doi.org/10.1348/096317909X478548

Vinnicomber, S., Doldor, E., Sealy, R., Pryce, P.\& Turner, C. (2015). The female FTSE Board Report 2015. Retrieved from https://www.cranfield.ac.uk/som/expertise/ changing-world-of-work/gender-leadership-and-inclusion-centre/female-ftseindex

Walsh, J. (2012). Not worth the sacrifice? Women's aspirations and career progression in law firms. Gender, Work and Organization, 19(5), 508-531. https://doi. org/10.1111/j.1468-0432.2012.00607.x

West, C., \& Zimmerman, D. (1987). Doing gender. Gender and Society, 1(2) 13-37. https://doi.org/10.1177/0891243287001002002

Wilén, N., \& Heinecken, L. (2018). Retendering the South African army: Inclusion, reversal and displacement. Gender, Work and Organization, 25(6), 670-686. https://doi.org/10.1111/gwao.12257 